\title{
Recent patents in gene transfer
}

\begin{tabular}{|c|c|c|c|c|c|}
\hline Patent \# & Subject & Assignee & Author & Date & Status \\
\hline GB 2331752 & $\begin{array}{l}\text { Reporter gene-labeled YAC vectors and transgenic mammals } \\
\text { allowing for more reliable gene transfer; used for screening } \\
\text { potential active agents. }\end{array}$ & $\begin{array}{l}\text { Medical Research } \\
\text { Council (London) }\end{array}$ & $\begin{array}{l}\text { Harmar AJ, } \\
\text { Schedl A, Shen S }\end{array}$ & $6 / 2 / 99$ & A \\
\hline WO 9925817 & $\begin{array}{l}\text { A nucleic acid flanked by binding sites for SB proteins } \\
\text { (transposase), used to identify enhancers and coding } \\
\text { sequences and for gene transfer. }\end{array}$ & $\begin{array}{l}\text { Univ. Minnesota } \\
\text { (Minneapolis, MN) }\end{array}$ & $\begin{array}{l}\text { Clark KJ, Dupuy AJ, } \\
\text { Ekker SC, Hackett PB, } \\
\text { Ivics Z, Izsvak Z, } \\
\text { Largaespada DA }\end{array}$ & $5 / 27 / 99$ & A2 \\
\hline WO 9924602 & $\begin{array}{l}\text { The parallel determination of cell vitality and efficiency } \\
\text { after gene transfer in eukaryotic cells by measuring } \\
\text { enzyme activity followed by determining reporter } \\
\text { gene activity. }\end{array}$ & $\begin{array}{l}\text { Max Delbrück Center } \\
\text { for Molecular } \\
\text { Medicine (Germany) }\end{array}$ & Groth D, Reszka R & $5 / 20 / 99$ & A2 \\
\hline WO 9923880 & $\begin{array}{l}\text { Detecting potential drug target proteins or determining } \\
\text { the effect of a drug candidate using somatic cell gene } \\
\text { transfer to mimic the action of the candidate drug. }\end{array}$ & $\begin{array}{l}\text { Johns Hopkins Univ. } \\
\text { (Baltimore, MD) }\end{array}$ & Marban E & $5 / 20 / 99$ & $\mathrm{~A} 1$ \\
\hline WO 9921591 & $\begin{array}{l}\text { A soluble ionic complex useful in the treatment of autoimmune } \\
\text { and hyperproliferative diseases through in vitro and in vivo } \\
\text { gene transfer. }\end{array}$ & $\begin{array}{l}\text { American Home } \\
\text { Products } \\
\text { (Madison, NJ) }\end{array}$ & $\begin{array}{l}\text { Musunuri S, } \\
\text { Satishchandran C }\end{array}$ & $5 / 6 / 99$ & A1 \\
\hline WO 9920773 & $\begin{array}{l}\text { Transcriptionally activated inverted terminal repeats, } \\
\text { useful for the production of adeno-associated virus } \\
\text { vectors for in vivo gene transfer. }\end{array}$ & $\begin{array}{l}\text { Targeted Genetics } \\
\text { (Seattle, WA) }\end{array}$ & Feldhaus AL & $4 / 29 / 99$ & A2 \\
\hline DE 19756864 & $\begin{array}{l}\text { Production of neuronal or glial progenitor cells from } \\
\text { embryonic stem cells; useful for the therapy of neural } \\
\text { defects, for cell-mediated gene transfer in the nervous } \\
\text { system, and for production of polypeptides in vitro. }\end{array}$ & Bruestle O & Bruestle O & $4 / 29 / 99$ & C1 \\
\hline WO 9917807 & $\begin{array}{l}\text { A composition comprising a nucleic acid and a vasoactive } \\
\text { drug for enhancing the uptake of nucleic acid by } \\
\text { mammalian tissue cells useful in in vivo gene therapy. }\end{array}$ & $\begin{array}{l}\text { Cobra Therapeutics } \\
\text { (Cambridge, UK) }\end{array}$ & $\begin{array}{l}\text { Hill SR, Thomson TA, } \\
\text { Thorp SY }\end{array}$ & $4 / 15 / 99$ & A1 \\
\hline US 5894060 & $\begin{array}{l}\text { Identification of a DNA sequence containing a human origin } \\
\text { of replication (hORI); useful in gene transfer to somatic cells. }\end{array}$ & Boulikas T & Boulikas T & $4 / 13 / 99$ & A \\
\hline WO 9915677 & $\begin{array}{l}\text { Stable and efficient gene transfer using a recombinant viral } \\
\text { vector encoding Bcl2 as well as a selected transgene. }\end{array}$ & $\begin{array}{l}\text { Univ. Pennsylvania } \\
\text { (Philadelphia, PA) }\end{array}$ & Chen S, Wilson JM & $4 / 1 / 99$ & $\mathrm{~A} 1$ \\
\hline WO 9915686 & $\begin{array}{l}\text { A dual selection cassette comprising eukaryotic viral vectors } \\
\text { with positive and negative selection genes operably linked } \\
\text { to their own promoters, for use in gene transfer. }\end{array}$ & $\begin{array}{l}\text { GenVec } \\
\text { (Rockville, MD) }\end{array}$ & $\begin{array}{l}\text { Brough DE, Kovesdi I, } \\
\text { McVey DL }\end{array}$ & $4 / 1 / 99$ & A1 \\
\hline US 5885276 & $\begin{array}{l}\text { A cryosurgery device for performing transmyocardial cryo- } \\
\text { revascularization; can be used for gene transfer since it } \\
\text { provides a low-temperature environment for introducing } \\
\text { vector particles, enabling maintenance of infectivity of } \\
\text { vector particles and myocardial tissue. }\end{array}$ & Galil Medical Ltd. & $\begin{array}{l}\text { Ammar R, Bliweis M, } \\
\text { Ofer G, Sturlesi GE }\end{array}$ & $3 / 23 / 99$ & $A$ \\
\hline JP 11056360 & $\begin{array}{l}\text { Gene transfer by electroporation, which involves transferring } \\
\text { foreign genes by electroporation for a predetermined } \\
\text { frequency and an electric pulse at a specified electric } \\
\text { field strength. }\end{array}$ & Iwate Ken (Japan) & - & $3 / 2 / 99$ & A \\
\hline WO 9905301 & $\begin{array}{l}\text { Gene transfer by retrovirus in a medium containing a } \\
\text { functional substance and optionally low-density lipoprotein; } \\
\text { useful in treating, e.g., AIDS and cancer. }\end{array}$ & $\begin{array}{l}\text { Takara Shuzo Co. } \\
\text { Ltd. (Shiga, Japan) }\end{array}$ & $\begin{array}{l}\text { Bagnis C, Imbert A, } \\
\text { Mannoni P }\end{array}$ & $2 / 4 / 99$ & $\mathrm{~A} 1$ \\
\hline CN 1201071 & $\begin{array}{l}\text { Counter virus-gene transfer carrier PLJF and its method } \\
\text { of preparation, for the treatment of malignant tumors such } \\
\text { as digestive tract cancer with TNF. }\end{array}$ & $\begin{array}{l}\text { No. } 1 \text { Hospital } \\
\text { Zhongshan } \\
\text { Medical Univ. (China) }\end{array}$ & $\begin{array}{l}\text { Lu S, Ren C, } \\
\text { Zhang H }\end{array}$ & $12 / 9 / 98$ & A \\
\hline
\end{tabular}

Source: Derwent Information, Alexandria, VA. ${ }^{*}$ The patents in the table are pending. The status of each application is slightly different from country to country. For further details, contact Derwent Information, 1725 Duke St., Suite 250, Alexandria, VA 22314. Tel: 1 (800) DERWENT (info@derwent.com). 